\title{
Commentary: Timing for aortic surgery in rare genetic variants: When prevention warrants intervention?
}

\author{
Gianluigi Bisleri, MD, FRCSC
}

\author{
From the Division of Cardiac Surgery, Department of Surgery, Queen's University, Kingston, Ontario, Canada \\ Disclosures: Author has nothing to disclose with regard to commercial support. \\ Received for publication Oct 7, 2018; accepted for publication Oct 8, 2018; available ahead of print Nov 7, 2018 \\ Address for reprints: Gianluigi Bisleri, MD, FRCSC, Kingston Health Sciences Centre - Victory 3, 76 Stuart St, \\ Kingston, Ontario K7L 2V7, Canada (E-mail: gianluigi.bisleri@queensu.ca). \\ J Thorac Cardiovasc Surg 2019;157:e111-2 \\ $0022-5223 / \$ 36.00$ \\ Copyright (c) 2018 by The American Association for Thoracic Surgery \\ https://doi.org/10.1016/j.jtcvs.2018.10.022
}

Although clinical guidance for surgical intervention in patients with common syndromic forms of aortic disease (eg, Marfan, Ehlers-Danlos, and Loeys-Dietz) is well established, the indications in less frequent genetic conditions appear more challenging at present. In the current issue of the Journal, Norton and colleagues ${ }^{1}$ report an interesting case involving a 47-year-old female patient with a family history of thoracic aortic disease/dissection and with a PRKG1 mutation: Given the progression (over a decade) in the aortic diameters (root up to $37 \mathrm{~mm}$; ascending aorta up to $38 \mathrm{~mm}$ ), the authors opted for a prophylactic valvesparing root replacement procedure.

Maintenance of a proper contractile function in aortic smooth muscle cells (SMCs) plays a major role in the potential development of ascending aorta aneurysms and dissections. In fact, the most common heterozygous mutations identified as potential causes for inherited thoracic aortic aneurysms and dissections have been associated with genes leading to disruption of proteins involved in either SMC contraction (eg, ACTA2, MYH11, MYLK) or transforming growth factor-beta signaling 1 and 2 . $^{2}$

To date, the proportion of families with hereditable thoracic aorta disease and with a pathogenic variant in PRKG1 is estimated to be approximately 1\%. ${ }^{3}$ PRKG1 encodes a type I cGMP-dependent protein kinase (protein kinase $G$ type 1 ), which is activated on binding of cGMP and controls SMC relaxation. Although rare variants of PRKG1 mutations can be found in patients with hereditable thoracic aorta disease and in the general population, the only variant confirmed to cause aortic disease is a single heterozygous PRKG1 mutation, p.Arg177Gln (designated as p.R177Q). In the current report, Norton and colleagues ${ }^{1}$ identified a mutation p.R192Q that has not been widely described to date.

Furthermore, it is known that the SMCs form an elastincontractile unit with the extracellular matrix and the elastic lamellae in aortic wall. ${ }^{2}$ Intraoperatively, the authors identified an extremely fragile aorta, with diffuse increase in medial proteoglycan but without cystic medial degeneration

\section{References}

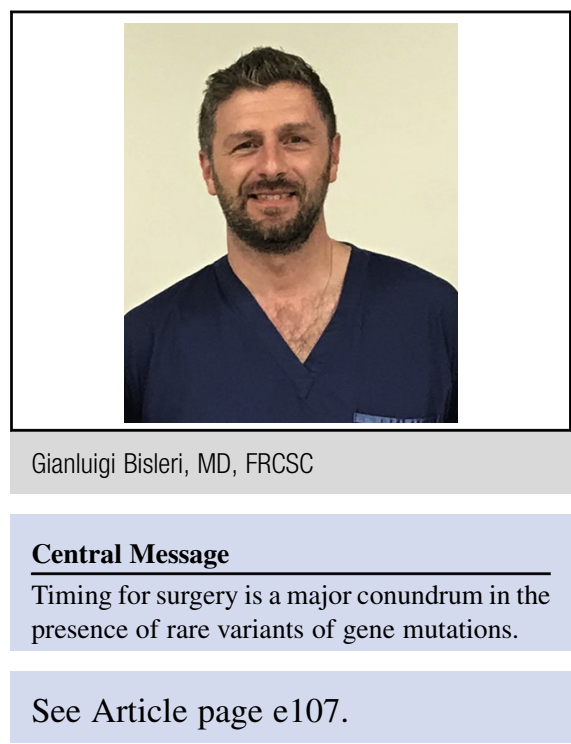

as typically observed in patients with Marfan or LoeysDietz syndrome. Of note, the presence of abnormal elastic lamellae may not be strictly indicative of abnormal disease, and the finding of a mild fragmentation of elastic fibers may not represent a major aortic wall abnormality per se. In general, it would be advisable to perform a thorough analysis and description of the aortic wall ${ }^{4}$ to provide important benchmarks in such rare instances.

Finally, with respect to the clinical history, it should be stressed that the patient presented with a relevant family history for aortic dissection ( 3 cases); as recently discussed by Saeyeldin and colleagues, ${ }^{5}$ the decision-making algorithm for patients with aortic disease is complex and must take several factors into account, including family history and not only size per se (which was well below the standard threshold for intervention in this case report).

Although the clinical strategy adopted by Norton and colleagues ${ }^{1}$ may have been successful in the present case, a careful integrated assessment of all potential factors (genetic, clinical, imaging based) should always be warranted until further understanding of such rare genetic variants is available.

1. Norton EL, Gordon D, Yang B. Managing the aorta in patients with a PRKGI mutation. J Thorac Cardiovasc Surg. 2019;157:e107-9.

2. Milewicz DM, Trybus KM, Guo DC, Sweeney HL, Regalado E, Kamm K et al. Altered smooth muscle cell force generation as a driver of thoracic aortic aneurysms and dissections. Arterioscler Thromb Vasc Biol. 2017;37: 26-33. 
3. Guo DC, Regalado E, Casteel DE, Santos-Cortez RL, Gong L, Kim JJ, et al. Recurrent gain-of-function mutation in PRKG1 causes thoracic aortic aneurysms and acute aortic dissections. Am J Hum Genet. 2013;93:398-404.

4. Halushka MK, Angelini A, Bartoloni G, Basso C, Batoroeva L, Bruneval P, et al. Consensus statement on surgical pathology of the aorta from the Society for Cardiovascular Pathology and the Association for European Cardiovascular
Pathology: II. Noninflammatory degenerative diseases - nomenclature and diagnostic criteria. Cardiovasc Pathol. 2016;25:247-57.

5. Saeyeldin A, Zafar MA, Li Y, Tanweer M, Abdelbaky M, Gryaznov A, et al. Decision-making algorithm for ascending aortic aneurysms: effectiveness in clinical application? J Thorac Cardiovasc Surg. November 14, 2018 [Epub ahead of print]. 